\title{
テーパー杭の水平抵抗に関する解析法 一実験結果との比較検討 - \\ ANALYTICAL METHOD FOR TAPERED PILE UNDER LATERAL LOAD \\ - Comparisons between predicted and experimental results -
}

\author{
冨永晃司 ${ }^{* 1}$, 陳 群 麗 ${ }^{* 2}$, 田村昌仁 ${ }^{* 3}$, 若井明彦*4 \\ Koji TOMINAGA, Qunli CHEN, Masahito TAMURA \\ and Akihiko WAKAI
}

\begin{abstract}
It was found in the book written by Peck R.B. and Hanson W.E (1953) that a driven tapered pile should have greater skin friction than that of a straight-sided pile. The authors have made the study on vertical behavior of a tapered pile installed by the press-in method, and proposed an analytical method based on non-linear Winkler model for the tapered pile. This paper presents the analytical method of a laterally loaded tapered pile considering both of non-linear behaviors of the pile and surrounding soil. On the other hand, the authors made the lateral loading tests on the steel pipe tapered piles in Kanto Loam. This paper also presents the outline of the tests, and comparisons between the lateral displacements and bending moments from the tests and predicted by the method. From the comparisons, it is found out that the predictions are in a fairly good agreement with the test results.
\end{abstract}

Keywords : Press-in method, Tapered pile, Lateral Load, Analytical method, Elasto-plastic behavior 圧入工法, テーパー杭, 水平荷重, 解析法, 弾塑性挙動

1. はじめに

建築物を支持する杭基礎として,杭頭から先端へと細くなるテーパ 一杭は，一様な径の直杭より支持能力の面で有利であることは古く Peck らの著書 $(1953)^{1)}$ でも指摘されている. そして，上部構造から伝 わる杭軸力は頭部から先端へと減少すること, 上部構造からの地震 時慣性力が杭頭に作用する場合には最大曲げモーメントが杭頭に生 じること，あるいは建筑物建設後に地盤沈下が発生寸る場合に負の 摩擦力が杭に作用することなど、杭の抵抗機構に関する諸条件に対 してもテーパー杭は有利であると考えられる.

このように抵抗機構に有利性のあるテーパー杭に関する既往の研 究は数が少なく, Rybnikov,A.M による場所打ちコンクリートの直杭 とテーパー杭との鉛直支持力に関する比較現場実験. ${ }^{2}$, 佐々木らによ る模型の直杭とテーパー杭の鈶直載荷比較実験 ${ }^{3)}$, あるいは Horvath, J.S.らによるジョン.F.ケネディー国際空港建設におけるテーパー杭の 支持力実験 ${ }^{4) .5}$ ，および J.K.Kodikara らによるテーパー杭の鉛直支持 力に関する解析法 ${ }^{6}$ など, 鉛直支持性能に関する研究が散見される程 度である.また, テーパー杭の水平抵抗に関する研究は, Reddy A.S. らによる杭を弾性体, そして杭一地盤系に地表面近傍から杭周辺地
盤が塑性化する現象を取り入れた Winkler モデルに基づく解析法 》 が提案されているに過ぎない.

上述したテーパー杭に関する研究の現況に鑑み，筆者らは圧入工 法により施工された低層建築物基礎として用いるテーパー杭の抵抗 機構に関する一連の研究を行っている. そして, まず文献 8)ではテ 一パー杭が圧入工法により施工される時の極限摩擦抵抗力として, 薄層要素モデルに円筒空洞押し拡げ弾塑性理論を適用した評価式を 提案すると共に, 高野の提案する杭先端極限支持力評価式 ${ }^{9}$ を取り入 れた押し込み力〜貫入量関倸に関する解析法を提示した。ついで， 佐賀県佐賀郡東与賀町における軟弱シルト地盤で実施した圧入施工 実験の結果と提案した解析法による解析結果との比較検討 ${ }^{10), 11)}$, お よび非線形 Winkler モデルに基づいたテーパー杭の水平抵抗に関す

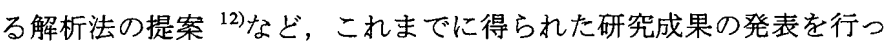
ている.

本論文は, 文献 12)で提案したテーパー杭の水平抵抗に関する解析 法を紹介すると共に, 関東ローム地盤で実施したテーパー杭の水平 載荷実験の紹介，およびこれらの実験結果と提案した解析法による 解析結果との比較検討した内容についても記述する.

\footnotetext{
*1 広島大学大学院国際協力研究科 教授 $\cdot$ 工博

*2 広島大学大学院国際協力研究科 特别研究員 ·博士 (工学)

*3 独立行政法人建築研究所国際地震工学センター 上席研究員 ·工博

*4 群馬大学工学部建設工学科 准教授・博士 (工学)

Prof., Graduate School for International Development and Cooperation, Hiroshima Univ., Dr. Eng.

Special Researcher, Graduate School for International Development and Cooperation, Hiroshima Univ., Dr. Eng.

Chief Research Engineer, International Institute of Seismology and Earthquake Engineering, Building Research Institute, Dr. Eng.

Assoc. Prof., Dept. of Civil Engineering, Faculty of Engineering, Gunma Univ., Dr. Eng.
} 


\section{2. 解析法の誘導}

テーパー杭は杭頭から先端へと先細りした形状であるため, 杭体 の曲げ剖性および杭体の水平変位に伴って発生する杭周辺地盤反力 は，杭軸方向で一様に扱うことができない。ここに，提案した本解 析法では図 1 (1) の解析全体モデルに示すように, Winkler モデルの 弾性支承梁理論に基づいた要素分割法を適用している。すなわち同 図(2)に示すように，ある要素（例えば，要素 $i$ ）の杭軸方向変断面 を一様断面として等価な曲げ哃性を有する線材に置換し，この要素 が周辺地盤から受ける水平地盤反力 $p_{i}$ は一様な水平地盤反力倸数 $k_{\mathrm{hi}}$ を有する連続ばねモデルで評価する，なお，筆者らの一連の研究で 扱うテーパー杭は，文献 8)で示したようにテーパー面の傾きの影響 が無視できる微小角度 $\theta$ (最大 $\theta=1 / 20$ まで : 水平成分が約 $0.1 \%$ の 誤差内）の杭を対象としており，各要素の水平地盤反力係数には杭 表面傾斜の影響を特に考慮していないことをお断りしておく.

上記の解析モデルによる実際の解析では，杭体の曲げ哃性および 水平地盤反力として，それぞれ杭体に発生する曲げモーメントおよ び杭と地盤間の相対水平変位（以降，水平変位と略称）に対匛した

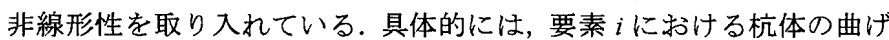
剛性 $K_{i}$ としては，図 1 (2) に示寸対象要素の上・下端（節点）で求 められた曲げモーメントの相加平均値から，その要素の曲げ哃性を 評価することとした．また，水平地盤反力の非線形性は，Winkler モ デルにおける地盤ばねに建築基礎構造設計指針 ${ }^{13}$ ）（以降，学会指針 と略称）の推奨式（水平変位 $y_{\mathrm{i}}$ の平方根に反比例する水平地盤反力 係数 $k_{h i}$ ) を適用し，この水平地盤反力係数 $k_{h i}$ を介して得られる水平 地盤反力 $p_{i}$ は，学会指針にならって塑性水平地盤反力 $p_{i y}$ を極限とし てこの值を超えない条件を与えることとした，なお，対象とする要 素の非線形ばねを評価するための水平変位は，杭体の曲渆性と同 様に要素上・下端の相加平均值を採用することとした.

以上の仮定の下, 要素 $i$ での基本方程式は次式で表される.

$$
\frac{d^{4} y_{i}}{d x_{i}^{4}}+\frac{k h i B_{i}}{K_{i}} y_{i}=0
$$

ここに, $B_{i}$ は要素 $i$ の平均杭径 $(\mathrm{m}), K_{i}$ は要素 $i$ の平均杭体曲げ 㓮性 $\left(\mathrm{kN} \cdot \mathrm{m}^{2}\right), y_{i}$ は要素 $i$ の平均水平変位 $(\mathrm{m})$ 抢よび $x_{i}$ は要素 $i$ の上端からの染さ（m）を表し，式 (1) の一般解は 4 個の未定積分 定数 $\left(A_{1} \sim A_{4}\right)$ を含む，次式で与えられる.

$$
y_{i}=e^{\beta i x i}\left(A_{1} \cos \beta_{i} x_{i}+A_{2} \sin \beta x_{i}\right)+e^{-\beta i x i}\left(A_{3} \cos \beta_{i} x_{i}+A_{4} \sin \beta_{i} x_{i}\right)
$$

ここに, $\beta_{i}=\left[k_{h i} B_{i} / 4 K_{i}\right]^{1 / 4}$ である.

上式の一般解に対して, 要素 $i$ 上端 $\left(x_{i}=0\right)$ で 4 個の物理量（水 平変位 $y_{i}$, 撓み角 $\theta_{i}$, 曲げモーメント $M_{i}$, せん断力 $\left.Q_{i}\right)$ を境界条件 として与えて未定積分定数を決定すれば, 要素 $i$ 中の各物理量に関す る一般式が定められる.これらの一般式を用いて要素下端 $\left(x_{i}=L_{i}\right)$ と上端の各物理量は, 次式のように関係つけられる.

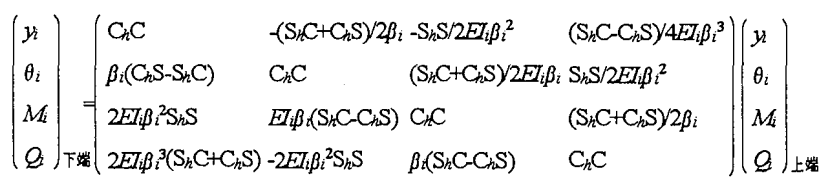

ここに, $\quad C_{h}=\cosh \left(\beta_{i} L_{i}\right), \quad S_{h}=\sinh \left(\beta_{i} L_{i}\right), \quad C=\cos \left(\beta_{i} L_{i}\right)$ およよひ $S=$ $\sin \left(\beta_{i} L_{i}\right)$ である。

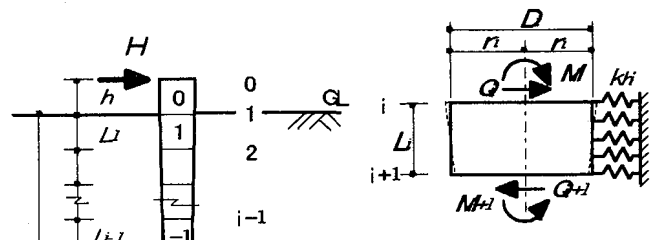

（2）要素 i の解析モデル

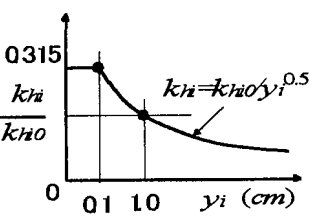

（khio：基準水平地盤反力保数）

（1）解析全体モデル （3）要素 i の地盤バネモデル

図 1 解析モデル

式 (3) における要素 $i$ 下端の各物理量は, 連続条件からその下要 素 $i+1$ の上端（ $x_{i+1}=0 ） に お け る$ 各物理量と同じである. したがっ て, 杭頭の各物理量を与えて上記の関係から杭先端へと各物理量を 順次伝達させることができ, 杭頭（添え字 $o$ ) と先端（添え字 $p$ ）の 各物理量を関倸付ける次式が導かれる。

$$
\left(\begin{array}{c}
y_{p} \\
\theta_{p} \\
M_{p} \\
Q_{p}
\end{array}\right)=\left(\begin{array}{llll}
a_{11} & a_{12} & a_{13} & a_{14} \\
a_{21} & a_{22} & a_{23} & a_{24} \\
a_{31} & a_{32} & a_{33} & a_{34} \\
a_{41} & a_{42} & a_{43} & a_{44}
\end{array}\right)\left(\begin{array}{c}
y_{o} \\
\theta_{o} \\
M_{o} \\
Q_{o}
\end{array}\right)
$$

この式に設計条件に適合する杭頭および先端の境界条件を与えて 杭頭之杭先端の未知量を決定し, 再び杭頭から先端へと各要素上下 端の関係式 (3) を適用して, 全節点の物理量を求めることができる.

上述した杭頭および先端の境界条件としては，一般的に杭頭では 自由 $\left(M_{0}=0, Q_{0}=H\right)$, 固定 $\left(\theta_{0}=0, Q_{0}=H\right)$ あるいは半固定(例 えば，固定度（杭頭固定に対する杭頭曲げモーメントの割合）ある いは杭頭回転ばね（杭頭撓み角と曲げモーメントを関係付ける回転 ばね）で表現）が与えられ，杭先端では自由（摩擦杭： $M_{\mathrm{p}}=0, Q_{\mathrm{p}}$ $=0$ ， ピン（支持杭： $y_{\mathrm{p}}=0, M_{\mathrm{p}}=0$ ）あるいは固定（杭先端が堅固 な層に根入れされた支持杭： $\left.y_{\mathrm{p}}=0, \theta_{\mathrm{p}}=0\right)$ 等が与えられる。これら の各境界条件を計算条件に照らして適用すれば，杭頭および杭先端 の未知の各物理量が定められる，具体例として杭頭自由および先端 自由を対象とすれば，式 (4) を既知と未知の物理量を考慮した部分 マトリックスで表現し直すと，以下の各式が得られる。ただし，式 中の添字の「末」は未定物理量、「既」は既知物理量を意味している.

$$
\begin{aligned}
& \left(\begin{array}{l}
M_{p} \\
Q_{p}
\end{array}\right)_{\text {既 }}=\left(\begin{array}{ll}
a_{31} & a_{32} \\
a_{41} & a_{42}
\end{array}\right)\left(\begin{array}{l}
y_{0} \\
\theta_{0}
\end{array}\right)_{\text {未 }}+\left(\begin{array}{ll}
a_{33} & a_{34} \\
a_{43} & a_{44}
\end{array}\right)\left(\begin{array}{l}
M_{0} \\
Q_{0}
\end{array}\right)_{\text {既 }} \\
& \left(\begin{array}{l}
y_{p} \\
\theta_{p}
\end{array}\right)_{未}=\left(\begin{array}{ll}
a_{11} & a_{12} \\
a_{21} & a_{22}
\end{array}\right)\left(\begin{array}{l}
y_{0} \\
\theta_{0}
\end{array}\right)_{未}+\left(\begin{array}{ll}
a_{13} & a_{14} \\
a_{23} & a_{24}
\end{array}\right)\left(\begin{array}{l}
M_{0} \\
Q_{0}
\end{array}\right)_{\text {既 }}
\end{aligned}
$$

ここに，境界条件による $M_{p}=0, Q_{p}=0, M_{0}=0$ および $Q_{0}=H$ を 式（5）に与えれば杭頭の未知物理量は決定でき, この結果を式（6） に代入して杭頭および杭先端の全物理量が決定できる。なお，他の 境界条件の組み合わせについても同様に行えばよい。ただし，杭体 曲代剛性 $K_{i}$ 就よび水平地盤反力係数 $k_{h i}$ は, それぞれ各要素の平均曲 げモーメントおよび平均水平変位に対応した值であるため, 各要素 のこれらの值は一義的に決定できなく, 以下の手順で繰り返し計算 
を行う必要がある.

1) 全要素に適当な $K_{i}$ および $k_{h i}$ 值を与え, 対象杭頭荷重（あるい は水平変位量）に対する全節点の物理量を計算する。

2) 手順 1)の計算結果による各要素の平均曲げモーメントおよび水 平変位から再決定される $K_{i}$ および $k_{h i}$ 值を用いて再計算を行う。

3 ）全節点におるおる手順 2)の再計算前の水平変位と再計算後のそれ らとの差が許容值以内にあるか否かの判定を行う.

$4 ）$ 手順 3)で否の場合は, 全節点の水平変位が許容值に収まるまで 手順 2) 3)を繰り返し，対象となる杭頭水平荷重（あるいは水平 変位量）に対する最適解を求める.

なお, 各要素の曲け剛性の非線形性は, 手順 2)〜4)において各要 素の平均曲げモーメントに対応した曲げ哃性により考慮されている。

上述したように，本解析法では各要素において杭体の非線形性お よび水平地盤反力の非線形性を考慮することができる。これに対し て文献 7)の解析法は，極限水平地盤反力に至るまでの水平地盤反力 を水平変位との線形関係（梁さ方向に一様な水平地盤反力係数を仮 定)で表していること, および杭体曲げ哃性を弾性範囲内に限定（杭 軸方向に関数化）していることなどが本解析法との主な相違である.

\section{3. 実験概要および実験結果}

\section{1 実験地盤および杭体}

本論文で対象とするテーパー杭の水平載荷実験は, 埼玉県猿島郡 境町で実施した。この実験敷地地盤は，地盤調查結果より地表面か ら約 $10 \mathrm{~m}$ までは粘性土化した軟弱な関東ロームが堆積していること が確認されている．実験に際して，敷地内の 6 測点 $(\mathrm{A}-\mathrm{F})$ でス ウエーデン式サウンディング試験（以降，SW S 試験と略記）を実 施した.これらの試験結果から文献 14）の提案式に基づいて換算し た $N$ 值（以降，換算 $N$ 值と略記）の深さ方向分布を図 2 に示してお く. 地盤調查結果および図 2 から，実験敖地内の地層には殆ど不陸 がなく, 深度約 $4.0 \mathrm{~m}$ までは $N \fallingdotseq 3$ のほぼ一様な粘性土層であり，そ
れ以深で $N=10 〜 15$ に増加する性状のあることが分かる，なお，䤡 管杭の他に木杭 1 本の水平載荷実験を実施したが, 木杭の材料定数 が不明であり，本論文の解析対象から除いたことをお断りしておく。

実験に供した鋼管杭は，直杭 1 本（SS140）およびテーパー角度 $\theta$ $\left(=\left(D_{o}-D_{p}\right) /(2 L), こ こ に D_{o}=\right.$ 杭頭径 (元口) , $D_{p}=$ 杭先端径 (末 口），および $L=$ 杭長）を変えたテーパー杭 3 本（ST200, ST260お よび ST380）である.これらの実験杭は，全て杭長 $3 \mathrm{~m}$ であり，圧 入工法にて実験地盤に設置したが，図 3 に示すように ST200 および ST380 は圧入途中で貫入不能となったため, 他の杭と同様に杭頭部 $0.2 \mathrm{~m}$ 残して切断している. なお，実験杭は所定の寸法に切断した 平鋼板を管状に成形し，全長溶接で作製されておりこれらの諸元 は表 1 に示す通りである。 なお，全杭において杭体内部の 3 断面に 対面同士の 4 箇所に歪みゲージを設置し，測定コードは杭内部空閒 を通して杭頭から取り出している.

このように全杭とも切断・加工・溶接等の製作工程を踏んでおり, かつテーパー形状であるため, 公称值による歪ゲージ設置位置の正 確な杭体剛性の評価は不可能に近い。したがって, 各杭体の圧入施 工前に弾性範囲内で作用荷重 $P$ (最大約 $100 \mathrm{kN}$ ) と各断面での歪值 $\varepsilon$ ( $\mu$ ) から軸剛性を求めるキャリブレーション試験を実施し,これらの 試験結果に基づいて各杭体の曲げ剛性を以下のように評価した。

いずれのキャリブレーション試験においても各断面における $P$ 〜 $\varepsilon$ 関係は, 最大荷重 $(P=100(\mathrm{kN}))$ までほぼ直線関係となる結果が 得られたため, まず $P=100(\mathrm{kN})$ とその時の歪值 $\left(\varepsilon_{100}(\mu)\right)$ から各 断面の較正係数 $\left(A E_{p}=P / \varepsilon_{100}\right.$, ここに, $A=$ 杭断面積, $E_{p}=$ 杭 弾性係数) を求めて表 2 に示した。 これらの較正係数（軸剛性）に 与える製造工程を含めた影響要因としては, 杭体の弾性係数 $E_{p} よ り$ 断面積 $A$ の方が影響度は高いと考えられる.したがって，杭体の弾 性係数として公称值 $\left(E_{p}=2.05 \times 10^{8} \mathrm{kN} / \mathrm{m}^{2}\right)$ を与えて得られる断面 積 $A$ を基に，杭体の見かけ上の平均肉厚 $t$ を求める.このようにし て求めた各杭の各断面における肉厚の評価値を表 3 に示した。この

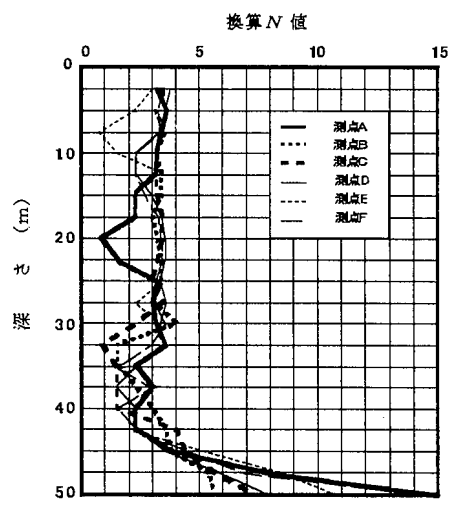

図 2 実験現場の SW S 試験による 換算N值分布

表 1 実験に供した杭の諸元

\begin{tabular}{|c|c|c|c|c|c|c|}
\hline \multirow[b]{2}{*}{ 名 称 } & \multicolumn{2}{|c|}{ 外 径 } & \multirow{2}{*}{$\begin{array}{l}\text { 長さ } \\
\text { (m) }\end{array}$} & \multirow{2}{*}{$\begin{array}{l}\text { 銅管厚 } \\
(\mathrm{mm})\end{array}$} & \multirow{2}{*}{$\begin{array}{c}\underset{\bar{\tau}-N^{0}}{\text { 角 }} \bar{\theta} \\
(\mathrm{rad})\end{array}$} & \multirow[b]{2}{*}{ 形状 } \\
\hline & $\underset{(\mathbf{m} m)}{\text { 元口 }}$ & $\begin{array}{c}\text { 末口 } \\
(\mathrm{mm})\end{array}$ & & & & \\
\hline SS140 & 139 & 139 & 3.00 & 4.0 & - & 자나 \\
\hline ST200 & 199 & 139 & 3.00 & 32 & $1 / 100$ & $\bar{\tau}-\Lambda^{\circ}-$ \\
\hline ST260 & 259 & 139 & 3.00 & 3.2 & $2 / 100$ & $\bar{T}-\Lambda^{0}-$ \\
\hline 51380 & 379 & 139 & 3.00 & 32 & $4 / 100$ & $\bar{\tau}-n^{\circ}-$ \\
\hline
\end{tabular}

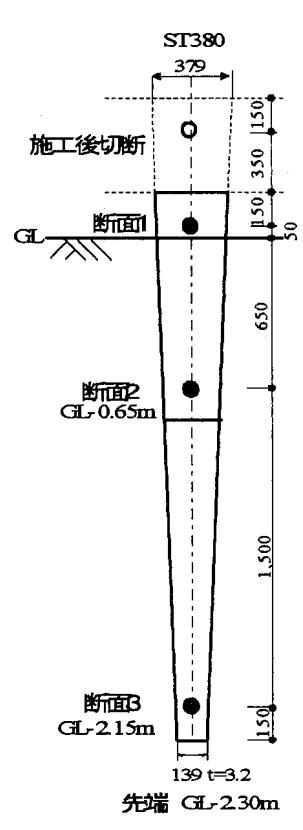

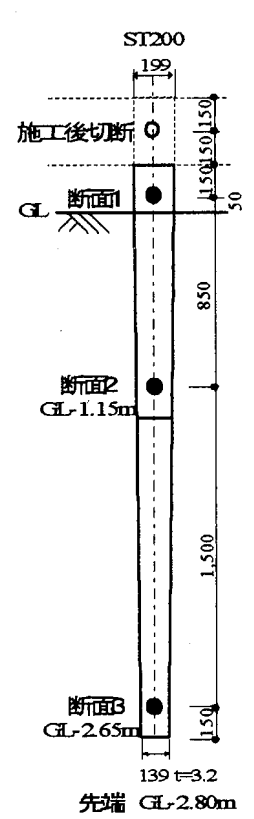

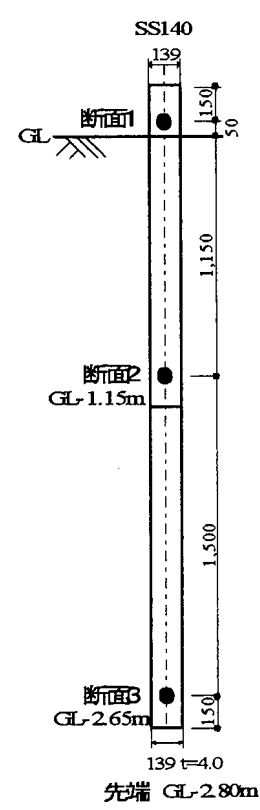

図3各実験杭の姿図 
表 2 各杭の各断面の較正係数

\begin{tabular}{|c|c|c|c|}
\hline \multirow{2}{*}{ 名 称 } & \multicolumn{3}{|c|}{ 較正倸数 } \\
\cline { 2 - 4 } & 断面 1 & 断面 2 & 断面 3 \\
\hline SS140 & 0.412 & 0.409 & 0.404 \\
\hline ST200 & 0.424 & 0.376 & 0.306 \\
\hline ST260 & 0.465 & 0.409 & 0.268 \\
\hline ST380 & 0.669 & 0.559 & 0.294 \\
\hline
\end{tabular}

表 3 各杭の各断面の換算肉厚

\begin{tabular}{|c|c|c|c|c|c|}
\hline \multirow{2}{*}{ 名 称 } & \multicolumn{4}{|c|}{ 換算肉厚 } & (mm) \\
\cline { 2 - 6 } & 断面 1 & 断面 2 & 断面 3 & 平均 & 公称值 \\
\hline SS140 & 4.77 & 4.73 & 4.67 & 4.72 & 4.0 \\
\hline ST200 & 3.42 & 3.40 & 3.35 & 339 & 3.2 \\
\hline ST260 & 2.89 & 3.05 & 2.81 & 292 & 3.2 \\
\hline ST380 & 2.85 & 3.10 & 2.85 & 2.94 & 3.2 \\
\hline
\end{tabular}

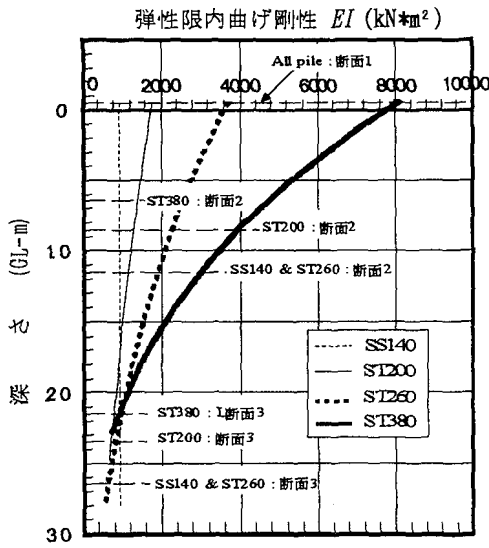

図 4 各杭の弾性限界内曲げ嗍性の 深さ方向分布

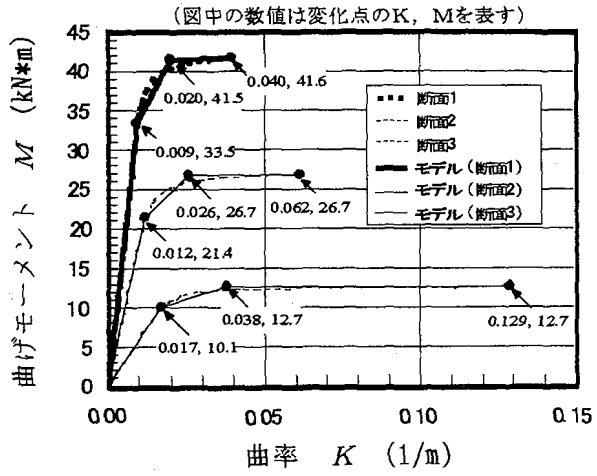

图 $5 M \sim K$ 関係とトリ・リニアモデル 之の関係例 (ST260)
表から，同一杭の各断面における評価された肉厚は若干異なった値 を示しているが，その誤差は小さいこと，およびこれらの平均值は 鋼板肉厚の公称值に対してもかなり近い值となっていることから， 各杭の曲げ剛性を評価するための肉厚としてこれらの平均肉厚（以 降、換算肉厚と呼称）を採用することとした。

上記の換算肉厚 $t$ および公称弾性係数 $E_{p}$ の他, 降伏応力度 $\sigma_{y}$ お

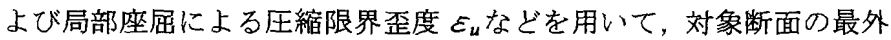
緣から杭断面内区分長ずつ媣部に順次塑性化を進行させる方法で $M$ 〜K関係を求め，テーパー杭の曲げ㴊性を定めることとした。ただ し，実際の解析における曲げ㣚性を求めるには，テーパー杭全長わ たる全要素 (図 $1 の(1)$ 参照) の $M \sim K$ 関係を関数化する必要がある. しかし，これらの $M \sim K$ 関係は数值積分法で算定しているため，陽 に関数表現することは不可能に近い，したがって，本論文では 3 本 の折れ線によるトリ・リニアモデルで表現することとした．

ここに，以下の諸定数を用いて算定した各杭の弾性限界内曲げ判 性の染さ方向分布，および $M \sim K$ 関係とトリ・リニアモデルとが成 す具体的関保として，ST260における断面 1 亿 3での例をそれぞれ 図 4 および図 5 に示した.

1)，杭体の降伏応力： $\sigma_{y}=2.4 \times 10^{6} \mathrm{kN} / \mathrm{m}^{2}$

2) 杭体の弾性係数 : $E_{p}=2.05 \times 10^{8} \mathrm{kN} / \mathrm{m}^{2}$

3) 杭軸方向区分長 : $L_{i}=0.05 \mathrm{~m}$ (全長 $3.0 \mathrm{~m}$ で 60 区分)

4) 杭断面内区分長 : $D_{i}=0.0001 \mathrm{~m}$

5) 压縮縁歪度限界値 : $\varepsilon_{u}=0.22 t / r^{15)}$ ( $r$ : 外半径)

なお，杭体の極限曲げモーメント（全塑性曲げモーメント $M_{u}$ と呼 称）は全断面が降伏応力あるいは圧縮側縁歪度が限界值に達した時 と定義し，トリ・リニアモデルの第 2 および第 3 折れ線は同モデル および $M \sim K$ 関係曲線の弾性限（降伏曲げモーメント $M_{y}$ と呼称）上 $M_{u}$ 間と横軸で囲まれた互いの面積が等しくなる条件で決定した．

\section{2 水平載荷実験およびその結果}

水平載荷実験は, 図 3 に示す杭頭突出部の地表面から約 $0.1 \mathrm{~m}$ 上部 に手動ジャッキおよびロードセルを介した布製バンドを設置し，鋼 製反力桁を反力として布製バンドを引っ張ることで水平加力する方 式で行った. 図 6 に実験杭の配置, 載荷方向（矢印）および歪ゲー ジ（A〜D）との関係などを示した. 害験時の測定事項は，杭頭水 平変位 $(\mathrm{GL}+0.1 \mathrm{~m})$ ，杭頭水平荷重および杭体曲代歪であり，これ

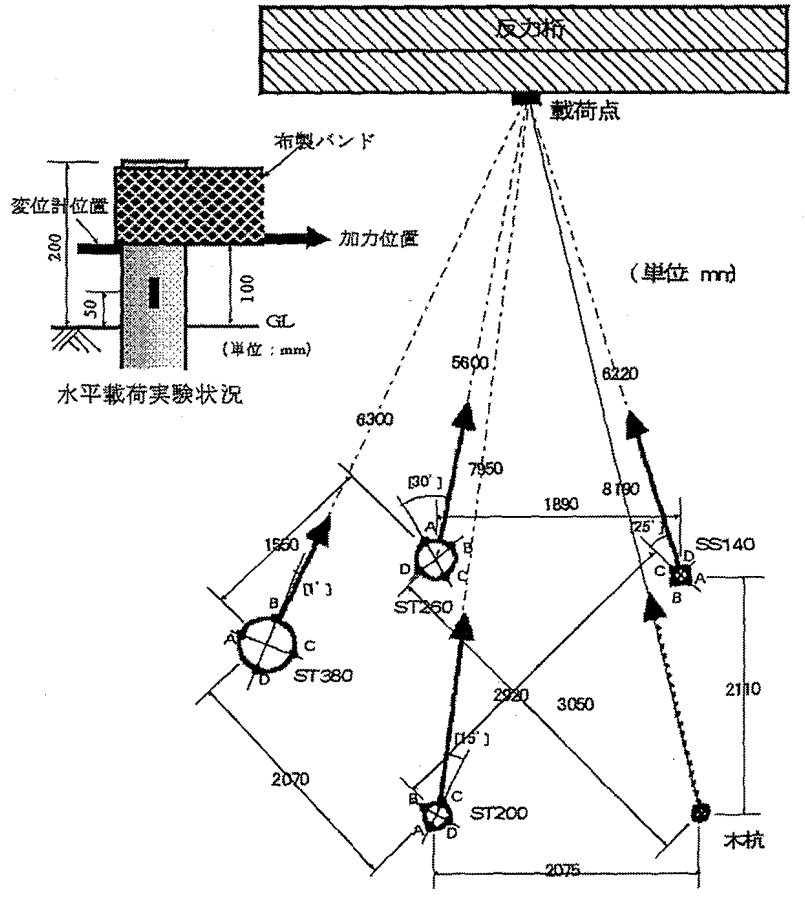

図 6 水平載荷状況、実験杭配置および載荷方向

らの測定は杭頭水平変位が約 $0.001 \mathrm{~m}$ 毎に行った。ただし，載荷は杭 全長にわたって弾性限界内に收まるように予測・設定した最大水平 荷重（後述の実験結果参照）までとした.

各水平載荷実験で得られた杭頭水平荷重 $H$ ～水平変位量 $y$ 関係を まとめて図７に，そして各解析値との比較のため図 8 中に黒四角印 で示した。また杭体曲げモーメントMに関しては，図 3 に示すよう に杭軸方向に 3 断面のみの測定であり，各変位階における曲げモー メントの梁さ方向分布より断面 2 の するとの判断から，図 8 中に黒四角印で示した。なお，図 6 に示さ れたように加力方向と歪ゲージ位置がずれているため，測定された 曲げ歪值を加力方向の值に置換して曲げモーメント值を求めている.

\section{4. 実験結果と解析結果との比較検討}

いずれの水平載荷実験も杭頭自由で杭先端が軟弱層にある状態で 
実施されているので, 解析における境界条件は杭頭と先端共に自由 とし, 載荷点および水平変位測定点は GL+0.1 $\mathrm{m}$ とした。なお，本実 験杭で対象となる地盤はシルト地盤であり，図 2 に示す換算 $N$ 值を 標準貫入試験 $N$ 值の代用として，解析に必要となる地盤の諸定数を 以下のように決定した。ただし，全ての杭が図 2 における $N \fallingdotseq 3$ の 範囲に根入れされていること，お上び圧入による杭の極近傍の周辺 地盤が締め固められる効果が期待できることなどを考慮して $N=3$ 〜 8 と $N$ 值を 1 ずつ変化させた一様地盤として解析を行っている.

各杭の各要素における基準水平地盤反力係数 $k_{h o}$ は，学会指針に 基づいて対象とする $N$ 值から求めた. 一方, 塑性水平地盤反力 $p_{y}$ を 定めるために必要なシルト層の単位体積重量 $\gamma$ は $15 \mathrm{kN} / \mathrm{m}^{3}$ とし, ま た粘着力 $C_{u}$ は，文献 16)で示されている一軸圧宿強度の換算式 $\left(q_{u}\right.$ $\left.=0.4+N / 20\left(\mathrm{kgf} / \mathrm{cm}^{2}\right)\right)$ から S I 単位へ変換した值を適用した。 なお, シルト地盤は小さな内部摩擦角 $\phi を$ 有しているとの指摘がある ${ }^{17)}$ が， 本論文では $\phi \fallingdotseq 0$ と仮定している.

地盤に関する上記の諸定数および前章で示した杭体および試験条 件による諸定数を用いて，実験結果を提案する解析法で解析した結 果として，まず $H \sim y$ 関倸曲線を比較して図 8 に示した。ただし， 解析は, 地中部最大曲げモーメントが全塑性曲げモーメント $M_{u}$ に達 するか，あるいは地盤がほぼ杭全長にわたって塑性水平地盤反力 $p_{y}$ に達するまで行っている。この図から, 以下のことが指摘できる.

1) いずれの杭も $\mathrm{N}$ 值が大きくなるほど $H \sim y$ 関係曲線は上方に位 置しているが、直杭（SS140）において，実験值と近似度が高いの は換算 $N$ 值（3.0）より大きな $N \doteqdot 5.0 の$ 結果が得られた。

2) テーパー杭の場合, ST200から ST380へとテーパー角が増大す るほど実験值に対応する $N$ 值は大きくなり，その值は ST200で $N$
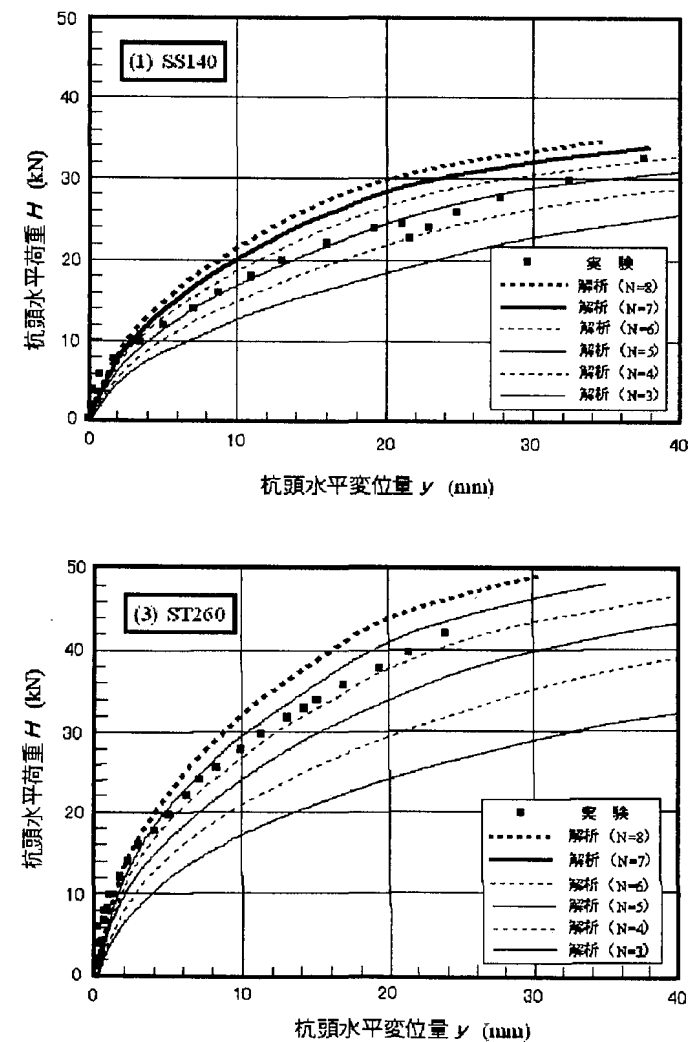

$\doteqdot 6.0, \mathrm{ST} 260$ で $N \fallingdotseq 7.0$ および ST380で $N \fallingdotseq 7.5$ となっている.

3) 上記 1)および2)で示された結果は，杭の圧入が直杭よりテーパ 一杭，そしてテーパー角の大きな杭へと杭周辺地盤を締め固める 効果を増大させることを示唆している.

ついで, 断面 2 に㧍ける曲げモーメントと杭頭水平変位量の関係 を図 9 に実験值と併記した。なお，同図中には断面 2 において最外 縁曲げ応力が降伏応力度 $\sigma_{y}$ に至る降伏曲げモーメント $M_{y}$ 值を記入 してある.ただし，この図の曲げモーメント解析に用いたN值は， それぞれの杭における $H \sim y$ 関係の実験值に近似する上記 2)に示し た值を採用している。これらの図から，以下のことが指摘できる.

4) SS140 杭は全体的に解析值が実験值を若千下回っているが、 ST200 および ST260 杭は杭頭水平変位量 $y$ が約 $15 \mathrm{~mm}$ (杭頭径の

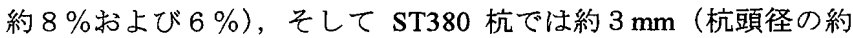
$0.8 \%$ ）の低変位領域で解析值は実験值とは良い一致を示している.

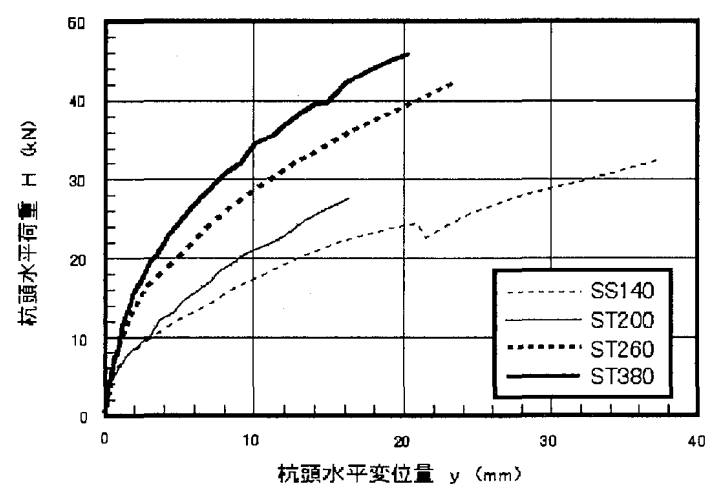

図 7 杭頭水平荷重 $H \sim$ 水平変位量 $y$ 関係に刮ける実験結果の比較
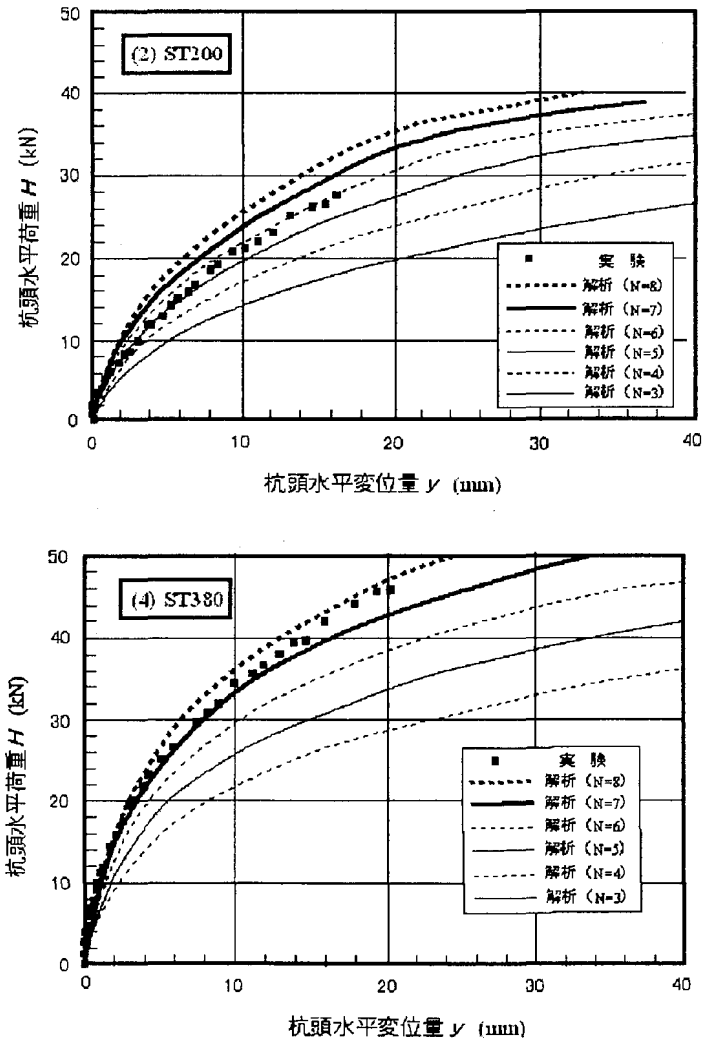

図 8 杭頭水平荷重 $H \sim$ 水平変位量 $y$ 関係における赛験結果と解析結果との比較 

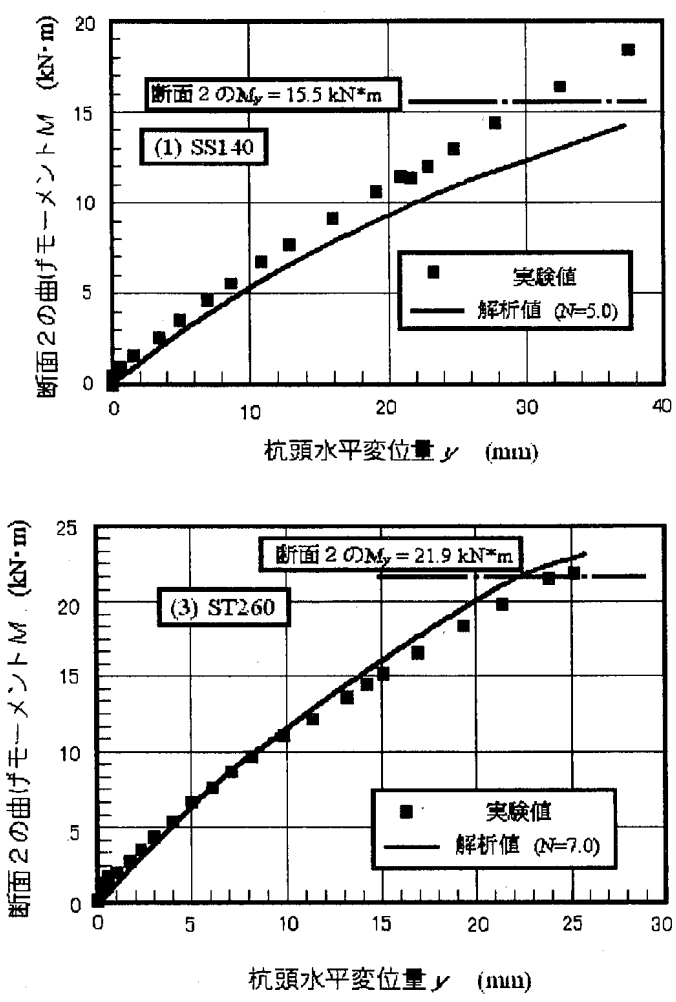
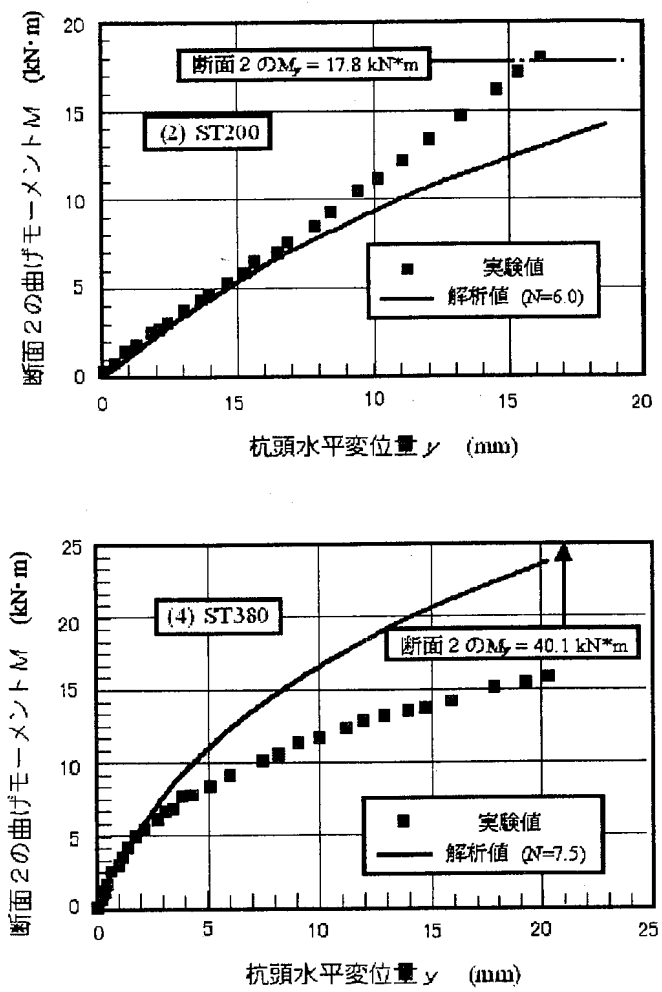

図 9 杭頭水平変位量 $y$ 断面 2 の曲げモーメント $M$ 関係

5）テーパー角 $\theta=2 / 100$ 杭（ST260）は $y$ が増大しても解析值は実 験值と良い一致を示しているが，直杭(SS140)およびテーパー角の 小さな $\theta=1 / 100$ 杭(ST200)では解析值が実験值を若干下回り, 反 対に $\theta$ の大な $\dot{\theta}=4 / 100$ 杭(ST380)では大きく上回る傾向がある。

\section{5. おわりに}

本論文では，既往の研究が稀少であるテーパー杭の水平抵抗問題 に関して，杭体および地盤の非線形性を取り入れた解析法を提案し た. また, 害テーパー杭の水平挙動性状を把握するため, 直杭およ び 3 種類のテーパー角の杭を用いて実施した水平載荷実験結果を示 し，これらの結果に対して提案した解析法による解析結果と比較検 討を加えた。検討結果として, $H \sim y$ 関倸と適合性の良い逆算 $N$ 值 を用いた解析結果であるにも関わらず，前章 5)で指摘したテーパー 角の違いが不一致性を生じさせている原因の詳細は，現在のところ 不明である、ただし，杭体に関する解析用諸定数の評価精度に対し て，地盤諸定数に関しては $N$ 值に基づいた学会指針などの推奨值を 採用したことに一因があると判断している。この点を改良する方法 については，今後さらに検討を加えていく予定である.

最後に, 本研究は平成 19 年度科学研究補助金(基盤研究(B): 18360267, 研究代表者：富永晃司)により実施しており，ここに記し て深甚の謝意を表す。

\section{参考文献}

1) Peck R.B. and Hanson W.E. : Foundation Engineering, John Willy, pp. 184-186, 1953.

2) A.M.Rybnikov: Experimental Investigations of Bearing Capacity of Bored Cast in Place Taper Piles., Soil Mechanics and Foundation Engineering,Vol.27, No.2, pp.48-52, 1990.2
3）佐々木隆光 他 3 名：テーパー杭の鉛直支持力に関する基磁的研究，第 38 回地盤工学会研究発表講演集, pp. 1407-1408，2003.7.

4) Horvath,J.S., T.Trochalides, A.Burns and S. Merjan. : Axial-Compressive Capacities of a New Type of Tapered Steel Pipe Pile at the John F. Kennedy Intemational Airport, paper No.11-02, Fifth Case Hist. Conf. on Geotech. Engrg., N.Y., NY, U.S.A., 2004

5) Horvath J.S. and Trochalides P.E.T. : A Half Century of Tapered-Pile Usage at the John F. Kennedy International Airport, Proceedings of Fifth International Conference on Case Histories in Geotechnical Engineering, Paper No.11.05, 2004.

6) J.K.Kodikara \& I.D.Moore : Axial Response of Tapered Piles in Cohesive Frictional Ground, Journal of Geotechnical Eng., Vol.119, No.4, ASCE, pp.675-693, 1993.4

7) Reddy A.S. and Ramasamy G. : Analysis of an Axially and Laterally Loaded Tapered Pile in Sand, Journal of the Japanese Society of Soil Mechanics and Foundation Engineering, Vol.13, No.4, pp.15-28, 1973.12.

8）冨永晃司、陳群霳:テーパー杭の鉛直押込み力〜沈下量関倸の一解析法; 日本建筑学会構造系論文集,第 603 号,pp.77-83,2006.

9）高野信昭：砂地盤に設置された NONDISPLACEMENT PILE の先端支持 力, 東京工業大学博士論文, pp.159-179,1981.3.

10）池田幸治,陳群麗,田村昌仁,若井明彦,冨永晃司：テーパー銅管杭の押し込 み施工実験(その 1: 奏験概要とその結果), 日本建築学会中国支部研究報 告集第 30 卷, pp.161-168, 2007.3.

11）池田幸治,陳群麗,田村昌仁,若井明彦,冨永晃司：テーパー銅管杭の押し込 み施工実験(その $2:$ 実験結果の解析)，日本建築学会中国支部研究報告集 第 30 卷, pp.161-168, 2007.3

12）奮世杰,陳群麗,富永晃司: テーパー杭の水平抵抗に関する一解析法, 日本 建筑学会中国支部研究報告集第 30 卷, pp.177-180, 2007.3.

13）日本建筑学会編：建築基礎構造設計指針, pp. 273-284, 2001.10.

14）日本建筑学会編：小規模建築物基礎設計の手引き,pp.29-31, 1997.4 .

15）日本建築学会編：建築基碟構造設計指針, pp.303-305, 2001.10.

16）大崎順彦著：建築基礎構造，技法堂出版, pp.399-400, 1991.1.

17）土質工学会（現：地盤工学会）編：土質基碳工学ライブラリー5ー建設 工事における土質工学の実用例一,pp. 271- 273, 1975.4 